\title{
Long-Distance Voicing Agreement: An Evolutionary Perspective
}

\author{
GUNNAR ÓLAFUR HANSSON \\ University of British Columbia
}

\section{Introduction}

Phenomena involving the long-distance assimilation of consonants (e.g., Ineseño /s-api-t $\int^{\text {h }}$ o-it/ $\rightarrow$ [Sapit $\int^{\text {h }}$ olit], Yaka /-mí:tuk-idi/ $\rightarrow$ [-mírtuk-ini]) have come under renewed scrutiny in recent years. ${ }^{1}$ Most notably, it has been argued that such phenomena involve not feature spreading but featural agreement, and are rooted in the psycholinguistic domain of phonological encoding for speech production (e.g., Walker 2000; Rose and Walker 2000, 2004; Hansson 2001). Some typical diagnostics of consonantal agreement systems are listed in (1):

(1) Salient characteristics of long-distance consonant agreement:

a. Highly sensitive to (triggered by) similarity of potential trigger-target pair.

b. Often sensitive to the proximity of target to trigger in the output string.

c. Displays certain asymmetries robustly attested in speech errors (direction of assimilation, "palatal bias" effects, etc.).

d. Very often restricted to morpheme-internal contexts, or to derivational (as opposed to inflectional) domains within the output string.

Nevertheless it remains unclear what it really means to say that such agreement has its roots in the speech planning domain. Is the link genuinely synchronici.e., grammar-internal - or merely diachronic ("phonologized speech errors"), or perhaps a combination of both? Does it hold for all agreement systems or just some, and how can we tell? Adopting the perspective of Evolutionary Phonology (Blevins and Garrett 1998, 2004; Blevins 2004a, b, to appear; Garrett and Blevins to appear), with its emphasis on the primacy of a diachronic mode of explanation for synchronic sound patterns, the problem can be approached by posing the following questions: (i) What are the diachronic pathways by which consonant agreement phenomena can and do arise? (ii) Do some, or perhaps all, agreement

\footnotetext{
${ }^{1}$ I am indebted to several people for helpful comments and feedback on the work presented here, especially Juliette Blevins, Andrew Garrett, Suzanne Gessner, Bruce Hayes, Beth Hume, Larry Hyman, Sharon Inkelas, Sharon Rose and Rachel Walker. All errors remain my own.
} 


\section{Voicing Agreement: An Evolutionary Perspective}

systems of a particular type arise by "unnatural" mechanisms-i.e., not through (listener-based) sound change but by analogical processes? (iii) Does a case-bycase examination of the diachronic origins of individual agreement systems shed light on the typological properties of those particular systems? (iv) Does such an examination help sharpen our understanding of consonant agreement, and elucidate its supposed relation to psycholinguistic factors of speech planning?

This paper attempts to address the above questions with respect to one particular subtype of long-distance consonantal assimilation phenomena: voicing agreement. Three central claims are made here. First of all, I argue that some of the clearest cases of voicing agreement are likely to be the secondary diachronic result of analogical processes. They may thus have little to do with factors of speech planning, at least as regards their origin or motivation. Secondly, these "unnatural" diachronic scenarios help explain certain anomalous aspects of the systems in question which raise serious difficulties for analyses appealing to factors of speech planning at the synchronic level. Finally, the remaining residue of attested [voice] agreement systems is rather more well-behaved, displaying a range of properties characteristic of the vast majority of agreement phenomena.

\section{Unnatural Histories of Voicing Agreement}

A closer look at the typology of the (rather few) attested voicing agreement systems reveals that nearly all cases (for surveys see Hansson 2001, Rose and Walker 2004) can be partitioned into the two categories in (2):

(2) Near-exhaustive categories of voicing agreement systems:

a. Languages which show (synchronically and/or diachronically) extensive tone-voicing interdependence - in particular interaction of Low tone and [voiced] obstruents - as well as tone-spreading processes.

b. Languages which have agreement in at least one other laryngeal feature as well, and where distributional evidence suggests that agreement in [voice] is explicitly patterned after agreement in the other feature(s).

It is proposed here that the cases in (2a) arise through analogical reanalysis. Fortuitous patterns of agreement at-a-distance in [voice], which are themselves ultimately an accidental byproduct of L(ow) tone spreading and L-induced voicing, are interpreted at face value: as [voice] agreement in its own right. The proposed explanation for the cases in (2b) is that they are due to analogical extension. An independently existing agreement pattern in some other laryngeal feature, such as [spread glottis] or [constr. glottis], is extended or generalized to encompass the class (or node) of laryngeal features as a whole, including [voice].

\subsection{Analogical Reanalysis of Tone-Voicing Interaction}

Cross-linguistically, laryngeal features are known to interact strongly with pitch and phonological tone (e.g., Hombert 1978). Phonetically, modal voicing has a f0- 
lowering effect; phonologically, [voice] often conditions L or blocks the presence of H (Hyman and Schuh 1974, Bradshaw 1999). Importantly, the tone-voicing correlation is bidirectional: L may condition [voice], just as [voice] may induce or facilitate L tone (Poser 1981, Bradshaw 1999).

The clearest case of tone-induced voicing is that of Yabem (Oceanic, Papua New Guinea; see Hansson 2004 for details and references). In this language, a lexical tone contrast (/áwé/ 'outside' vs. /àwè/ 'woman') goes hand in hand with voicing in obstruents, if any are present; obstruents are voiced in low-toned syllables, else voiceless (/típ/ 'all at once' vs. /dìb/ 'thud'). The dependence of obstruent voicing on tone, combined with a tone spreading process, results in prefixes agreeing in tone and voicing with a following root (e.g., /ká-táy/ 'I weep' vs. /gà-dèy/ 'I move towards' for 1.sg.realis /ka-/).

This state of affairs in Yabem gives the appearance of voicing agreement, though the identity in voicing values is fortuitous as such, being mediated by tone. What is more, the "agreement" even seems to show a similarity restriction (cf. (1a) above) in that the sole fricative /s/ fails to interact with stops (cf. /sàgìn/ 'house partition', /dà-sà?/ 'we (incl.) put on top of'). However, the apparent similarity restriction simply results from a general devoicing of earlier $*_{z}$ in the recent history of Yabem, which obliterated $[\mathrm{z}] \sim[\mathrm{s}]$ alternations. See Hansson (2004) for a full analysis of Yabem tone-voicing interaction in Optimality Theory.

\subsubsection{Voicing Agreement and Tone-Voicing Interaction in Kera}

Only one case is attested where voicing agreement results in overt alternations: Kera (East Chadic, Chad; Ebert 1979a, Walker 2000, Hansson 2001, Uffmann 2003, Rose and Walker 2004). With extremely few exceptions, voiced and voiceless pulmonic plosives do not cooccur in this language (unless noted otherwise, all data is cited from Ebert 1979a):

(3) Voicing agreement in Kera words:

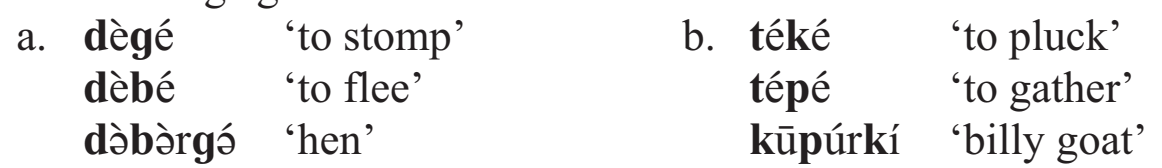

Alternations in [voice] are most clearly visible in words containing nominal affixes with $/ \mathrm{k} /$ (surfacing as $[\mathrm{k} \sim \mathrm{g}]$ ), as in (4):

(4) Affix alternations due to voicing agreement:
a. $/ \mathrm{k}+\operatorname{sir}+\mathrm{ki} /$
$\rightarrow$
kīsírkí
'black (masc.)'
/k + dzàr + káy/ $\rightarrow$
gòdzàrgán
'colourful (coll.)'
b. $/ \mathrm{k}+$ taitá + w/ $\rightarrow$
kə̄tā:táw
'cooking pots'
$/ \mathrm{k}+$ dzà:nà + w/ $\rightarrow$
gə̀dzà:yáw
'footstools' 


\section{Voicing Agreement: An Evolutionary Perspective}

Among the general class of obstruents, it appears that neither implosives nor (pulmonic) fricatives participate in the voicing agreement. As illustrated in (5), voiced implosive stops freely cooccur with voiceless and voiced pulmonic stops alike (5a), and voiceless fricatives freely cooccur with voiced stops (5b).

(5) Implosives and fricatives are neutral/immune to voicing agreement:
a. dígí 'to think' dúpí 'to scoop (pl.)'
bálgé 'to spoil' bókáj [no gloss]
gùbí 'to shut in' tférdé 'to press'
b. fêrgé 'to itch' (<*vèrgé)
dèfé 'to make [sauce]' $\quad(<*$ dèvé $)$

Both of the limitations in (5) could be attributed to a similarity restriction (Rose and Walker 2004; cf. Hansson 2001). However, there are two reasons why this is less than ideal. For one thing, the apparent failure of fricatives to participate in voicing agreement in (5b) is clearly the secondary result of a general devoicing of voiced fricatives (almost universal for $/ \mathrm{z} />/ \mathrm{s} /$, sporadic for $/ \mathrm{v} />/ \mathrm{f} /$ ). The original voicing values can in fact usually be inferred from the tone pattern; once these are "restored," few if any cases remain of voicing disagreement in words mixing plosives with fricatives. In its original form, then, agreement must have targeted all (pulmonic) obstruents. Secondly, to interpret implosives as being consistently dissimilar to pulmonic obstruents creates severe problems with respect to the similarity metric; see section 2 below for detailed discussion.

As it turns out, there is extensive interaction between tone and laryngeal features in Kera, as in many other languages of the Chadic family (Ebert 1979a, b; Pearce 1998/99). More specifically, [voice] in obstruents frequently conditions Low tone. For example, in verbs, a root-initial voiced obstruent forces the following vowel to be $\mathrm{L}$ (6a) rather than $\mathrm{M}$ or $\mathrm{H}(6 \mathrm{~b})$ :

(6) Kera verbs: tone predictable based on consonants (from Pearce 1998/99)
a. /zald-ú/ zàld-ú 'hit him'
b. /mirk-ú/ mírk-ú 'greet him'
/zald-m/ zàld-àm 'hit you (m.)'
/mirk-m/ mīrk-īm 'greet you (m.)'
/gun-ú/ gùn-ù 'awaken him'
/gun-m/ gùn-ùm 'awaken you (m.)'

The $\mathrm{L}$ induced by the voicing of a root-initial obstruent is involved in several processes: (i) L blocks leftward spread of $\mathrm{H}$ from a H-toned suffix such as /-ú/; (ii) L spreads to a toneless prefix or suffix vowel (often epenthetic, but not always); (iii) under certain conditions, $\mathrm{L}$ spreads to a H-toned suffix, delinking the $\mathrm{H}$ (e.g., in /gun-ú/ $\rightarrow$ [gùn-ù] $)$.

In all cases of affixal [voice] alternations as in (4), e.g., /k-dzà:yà-w/ $\rightarrow$ [gà-dzà:yá-w], the voicing-induced L of the root-initial syllable spreads to an (epenthetic) prefix vowel. As a result, voicing agreement is seen to reach across a 
L vowel. Likewise, when voicing passes from root to suffix (e.g., /-dzàr-káy/ $\rightarrow$ [-dzàr-gán]), the intervening root vowel is by necessity low-toned, cf. (6a) above.

This appears to be a general distributional pattern in Kera; two agreeing [+voiced] obstruents are always separated by a low-toned vowel/rhyme. What is more, the following example suggests that an intervening $\mathrm{L}$ is in fact a necessary condition for voicing agreement to take place:

$$
\begin{aligned}
& \text { Voicing agreement blocked by intervening H? (from Pearce 1998/99:51) } \\
& \text { /k-ágàj/ } \rightarrow \text { kógàj 'hoes' (not**gógàj) }
\end{aligned}
$$

In sum, there is considerable evidence suggesting that (low) tone is implicated in creating the Kera voicing agreement pattern, if not synchronically then at least at some diachronic stage. Whether the two agreeing obstruents are in a single root (e.g., [dèbé]), a root-suffix sequence (e.g., [-dzàr-gáy]), or a prefix-root sequence (e.g., [gว̀-dzà:yá-w]), the intervening L may in fact be the culprit directly responsible for the voicing of one of the obstruents - much like in Yabem above.

\subsubsection{Voicing Agreement and Tone in Ngizim}

Voicing agreement, by the regressive assimilation in [voice] between pulmonic obstruents, is also attested in another Chadic language, Ngizim (West Chadic, Nigeria; Schuh 1997; see Hansson 2001). Historically, morpheme-internal *T...D sequences were harmonized to D...D (though borrowings have given rise to new, disharmonic T...D sequences). Fricatives participate in the agreement, but just as in Kera, implosives fail to interact with their pulmonic counterparts:

(8) Voicing agreement in Ngizim (data from Schuh 1997):

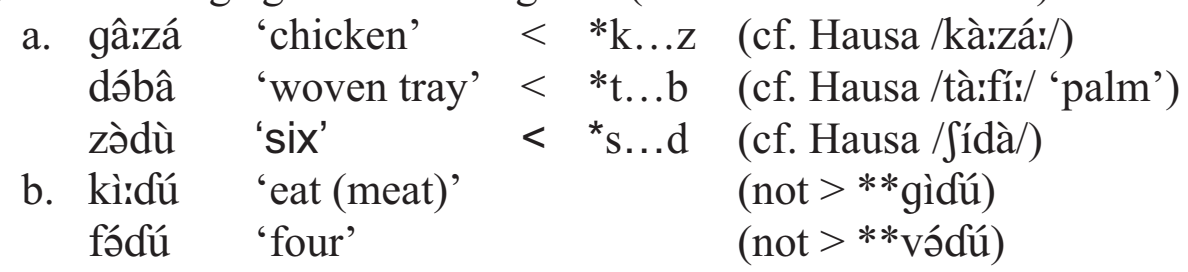

There is no obvious connection between tone patterns and the voicing agreement (and the agreement is probably not synchronically active). Nevertheless, there is clear and ample evidence of interaction of low tone with obstruent voicing in Ngizim, both in the diachronic development of tone and in synchronic tonal processes (Schuh 1971, Bradshaw 1999); in all such cases, (voiced) implosives pattern with voiceless obstruents rather than with voiced ones. Given the pervasive connection between L and [voice] in Ngizim phonology (synchronic as well as diachronic), and given the fact that implosives pattern alike in tonal processes and in voicing agreement, it is at least a plausible conjecture that tone may have been implicated in the historical development of voicing agreement. 


\subsection{Analogical Extension of Other Laryngeal Agreement?}

In a small number of cases, agreement in [voice] coexists with agreement in another laryngeal feature, either [spread glottis] or [constricted glottis]; the overall pattern is thus a three-way laryngeal agreement system. As demonstrated in this section, evidence suggests that voicing agreement has a secondary status and likely results from analogical extension or expansion of a previous two-way system to a three-way one. A shared property of these languages is the limitation of laryngeal agreement to plosives, excluding fricatives.

\subsubsection{Voicing and Aspiration Agreement in Zulu and Ndebele}

A general morpheme-internal laryngeal harmony among (non-click) stops holds in Zulu and Ndebele (Bantu, S. Africa/Zimbabwe; Khumalo 1987, Hyman 1999, Hansson 2001). Other things being equal, roots with multiple stops have only $\mathrm{T}^{\mathrm{h}} \ldots \mathrm{T}^{\mathrm{h}}, \mathrm{T} \ldots \mathrm{T}$, or $\mathrm{D} \ldots \mathrm{D}$, never disharmonic sequences like $* \mathrm{~T} \ldots \mathrm{T}^{\mathrm{h}}$ or $* \mathrm{~T}^{\mathrm{h}} \ldots \mathrm{D}$ :

(9) Harmonic roots in Zulu (Khumalo 1987):
a. $-\mathbf{k}^{\mathbf{h}} \mathrm{et}^{\mathbf{h}} \mathbf{a}$ 'to choose' $-\mathbf{p}^{\mathbf{h}}$ at ${ }^{\mathbf{h}} \mathbf{a}$ 'to hold'
b. -peta 'to dig up' -tapa 'to collect'
c. -guba 'to dig'

(10) Agreement enforced in Zulu loanword adaptation (Khumalo 1987):
a. í-k $\mathbf{k}^{\mathbf{h}} \hat{\mathbf{t}}^{\mathbf{h}} \mathbf{O}$ 'court' (from English court $/ \mathbf{k}^{\mathbf{h}} \mathbf{\jmath} \mathbf{t} /$ )
b. úm-bídi 'conductor' (from English beat/bit/)

Aspiration agreement, in Zulu and Ndebele alike, is overridden by a restriction limiting $\left[\mathrm{k}^{\mathrm{h}}\right]$ to root-initial position (Khumalo 1987, Hyman 1999, Hansson 2001), as shown in (11a). ${ }^{2}$ However, when the two stops are homorganic, it is agreement that instead overrides the ban against non-initial $\left[\mathrm{k}^{\mathrm{h}}\right](11 \mathrm{~b})$.

(11) Aspiration agreement and medial $\left[\mathrm{k}^{\mathrm{h}}\right]\left(\right.$ Ndebele data from $\left.\mathrm{CBOLD}^{3}\right)$ :
a. $-\mathbf{p}^{\mathbf{h}} \mathrm{eka}$
$-\mathbf{t}^{\mathrm{h}}$ ikaza
'cook, brew'
'be disturbed'
$\left(\right.$ not $\left.* *-p^{\mathrm{h}} \mathrm{ek}^{\mathrm{h}} \mathrm{a}\right)$
(not $* *-\mathrm{t}^{\mathrm{h}} \mathrm{ik}^{\mathrm{h}}$ aza)
b. $-\mathbf{k}^{\mathrm{h}} \mathbf{o} \mathbf{k}^{\mathrm{h}} \mathrm{a}$
$-k^{\mathrm{h}} \mathbf{u} \mathbf{k}^{\mathrm{h}} \mathrm{ula}$
'pull, draw out'
'sweep away'

Voicing agreement behaves in the exact same way with respect to non-initial velars. If the trigger is a heterorganic stop (labial or coronal), agreement is thwarted, resulting in medial $[\mathrm{k}]$ as in (12a). If the trigger is a homorganic stop (velar), then agreement is enforced, giving rise to medial $[\mathrm{g}](12 \mathrm{~b})$.

\footnotetext{
${ }^{2}$ Strictly speaking, $\left[\mathrm{k}^{\mathrm{h}}\right]$ does not need to be in absolute root-initial position, as long as it is the first consonant within the root (cf. Ndebele /-ak ${ }^{\mathrm{h}} \mathrm{a} /$ 'build', /-ok $\mathrm{h}$ a/ 'roast').

${ }^{3} \mathrm{CBOLD}=$ Comparative Bantu On-Line Dictionary, lexicographic database accessible at

$<$ http://www.ddl.ish-lyon.cnrs.fr/bdd/cbold/>.
} 
(12) Voicing agreement and medial [g] (Ndebele data from CBOLD):
a. -dakwa
'be drunk'
(not **-dagwa)
-dikisa
'palpitate, twitch' (not**-digisa)
b. -guga
'wear out'

The problem is that Zulu/Ndebele does not have any prohibition against medial [g] that could account for (12a) vs. (12b). In contexts where agreement is not at stake, non-initial $[\mathrm{g}]$ freely occurs (unlike $\left[\mathrm{k}^{\mathrm{h}}\right]$ ), cf. /-fuga/ 'push a cart', /-huga/ 'allure, entice', /-lagisa/ 'send cattle to grazing place', etc. Instead, it seems that the patterning of voicing agreement with respect to targeting of velars (and the role of trigger-target homorganicity) is somehow modelled after the patterning of aspiration agreement with respect to the same factors. The latter is simply interacting with independently validated phonotactic restrictions.

These facts suggest that voicing agreement in Zulu and Ndebele arose through the analogical generalization or "promotion" of aspiration agreement to an allencompassing laryngeal agreement (subsuming [voice]). Although much is yet unclear about the precise mechanism underlying such a development, agreement in [voice] thus appears to be of secondary origin in this case as well. ${ }^{4}$

\subsubsection{Voicing and Ejection Agreement in Chaha}

Root-internal laryngeal harmony among stops also occurs in Chaha, a Gurage dialect (Semitic, Ethiopia; Rose and Walker 2000, 2004). The features involved are [voice] and [constr. glottis], separating three series of voiced, voiceless, and ejective stops. The agreement, illustrated in (13), is most consistently enforced between stops which are adjacent within the consonantal root (e.g., /t'ik'ir/ 'hide!') but it is also highly significant between non-root-adjacent stops (e.g., /t'iß $\mathbf{i} \mathbf{k}$ '/ 'be tight!'; see Rose and Walker 2004). ${ }^{5}$

(13) Laryngeal agreement in Chaha roots (from Rose and Walker 2004)
a. k'it'ir 'kill!'
b. gidir 'put to sleep!'
c. kitf 'hash [meat]!' nit'ik' 'snatch!' əd(i) $\mathbf{g}$ 'make fall!'
tiks 'set on fire!'

Comparison with related languages reveals evidence that regressive assimilation has taken place in roots mixing ejectives and voiced stops, as illustrated in (14).

\footnotetext{
${ }^{4}$ See Hansson (2001) for arguments that coronal agreement in Tahltan (Athapaskan; British Columbia) has undergone a similar expansion from a two-way to a three-way system. Note further that the very origin of the [voiced] stop series as such in Zulu/Ndebele is somewhat unclear. Finally, Larry Hyman (p.c.) suggests that it is at least conceivable that tone has played a role in the development of Zulu/Ndebele voicing agreement as well, as $\mathrm{L} /[$ voice] interaction is rampant in these languages.

${ }^{5}$ It should be noted that, due to the usual Semitic OCP-Place restrictions on root consonants, nearly all of the relevant stop combinations are heterorganic.
} 
(14) Comparative evidence of regressive assimilation (Rose and Walker 2000):

\begin{tabular}{|c|c|c|}
\hline \\
\hline haha & Amharic & \\
\hline wit' & widək' & 'snatch!' \\
\hline . & $\begin{array}{l}\text { k'ida } \\
\text { mit'ad }\end{array}$ & $\begin{array}{l}\text { ‘draw liquid!' } \\
\text { 'griddle!' }\end{array}$ \\
\hline
\end{tabular}

Interaction between [voiced] and [constricted glottis] stops might be seen as a restriction against the cooccurrence of stops with conflicting (privative) laryngeal features. Such effects are attested elsewhere, e.g., in 'Peruvian' Aymara (MacEachern 1999, Hansson 2001), where [constr.gl.] stops and [spr.gl.] stops cannot cooccur $\left({ }^{*} \mathrm{~K}^{\prime} \ldots \mathrm{T}^{\mathrm{h}},{ }^{*} \mathrm{~T}^{\prime} \ldots \mathrm{K}^{\mathrm{h}},{ }^{*} \mathrm{~K}^{\mathrm{h}} \ldots \mathrm{T}\right.$, etc.), though each freely cooccurs with the plain stops which lack laryngeal specifications (i.e., $\mathrm{K}^{\prime} \ldots \mathrm{T}, \mathrm{T}^{\mathrm{h}} \ldots \mathrm{K}$, etc.).

Comparison with related languages has yet to reveal direct evidence of agreement being actively implemented through assimilation in the case of voiced/plain combinations (D...K, K...D, etc.) or ejective/plain combinations (T'...K, K...T', etc.), though such combinations are virtually nonexistent in the Chaha lexicon. Interestingly, in their database of 855 verb roots, Rose and Walker (2004) find only a single exception to "pure" agreement in [constr.gl.] agreement (of the type K'...T, T'...K, etc.), but numerous exceptions to "pure" agreement in [voice] (of the kind G...T, D...K, etc.). It thus seems that agreement in voicing is less strictly enforced in Chaha than agreement in ejection. Moreover, Rose and King (2003) found that Amharic has a significant cooccurrence restriction on root-adjacent stops differing only in [constr.gl.], but no corresponding restriction on stops differing only in [voice], indicating that any voicing agreement observed in Chaha is a later innovation.

\section{Inertness of Implosives and the Similarity Metric}

Recall that in the Chadic languages discussed in section 1.1, implosives are inert, consistently failing to trigger voicing agreement, unlike their pulmonic congeners (stops and fricatives). Thus words like Kera /dúpí/ 'to scoop (pl.)' or Ngizim /fádú/ do not get "repaired" to **[đúbí] and **[vádú], respectively. The analysis of voicing agreement as similarity-driven correspondence (Walker 2000, Hansson 2001, Rose and Walker 2004) has no recourse but to interpret the lack of interaction in these cases as a similarity effect. In other words, the level of similarity which holds between an implosive and a (voiceless) pulmonic obstruent must be below the threshold at which agreement becomes mandatory.

Recent work has suggested that segment-to-segment similarity is best calculated in terms of the set of distinct natural classes arising from the segment inventory of the language in question, and the degree of overlap in the sets of natural classes to which the two segments belong (Frisch 1996, Frisch et al. 2004). 


\section{Gunnar Ólafur Hansson}

Similarity metric based on distinct natural classes:

Similarity $=\frac{\text { Shared natural classes }}{\text { Shared natural classes }+ \text { Non - shared natural classes }}$

Unfortunately, however, the metric in (15) - as well as one based on simple feature-counting - makes incorrect predictions for implosives in Kera and Ngizim (Hansson 2001). In both languages, agreement applies to all pairs of pulmonic obstruents, even those which differ in place of articulation and/or manner. By contrast, a pulmonic-implosive pair is not subjected to agreement even when the two segments are identical in all other features. Consequently, if agreement is indeed automatically triggered by a high degree of similarity, we must assume that heterorganic stop-fricative pairs like $* / \mathrm{t} \ldots \mathrm{v} /$ or $* / \mathrm{f} . . \mathrm{d} /$ (banned due to agreement) are in fact being counted as "more similar" than homorganic stop-stop pairs like $/ \mathrm{t} \ldots \mathrm{d} /$ or $/ 6 \ldots \mathrm{p} /$ ! This is incompatible with any reasonable similarity metric, including the natural-class-based one above. Representative figures are shown in (16) for /t...v/ vs. /t...d/ in Ngizim; the similarity of /t/ to /d/ is several times greater than that of $/ \mathrm{t} / \mathrm{to} / \mathrm{v} /$, and yet the former fails to trigger agreement.

(16) Similarity values given Ngizim segment inventory: ${ }^{6}$
a. $/$ t...d $/:$
$21 /(21+24)=0.47$
(harmony not triggered)
b. $/$ t...v $/$ :
$7 /(7+57)=0.11$
(harmony triggered)

If, however, voicing agreement in Kera and Ngizim is instead due to analogical reanalysis of tone-voicing interaction effects, then the inertness of implosives is entirely as expected. In Kera, for example, the (voiced) implosives pattern with voiceless obstruents rather than with voiced pulmonic obstruents in their interaction with tone. In verbs, a root-initial implosive or voiceless obstruent forces the following vowel to be $\mathrm{H}$ rather than $\mathrm{L}$ (17); in nouns the same consonants force the vowel to be either $\mathrm{M}$ or $\mathrm{H}$, not $\mathrm{L}$ (18):

(17) Kera verb tones and phonation of root-initial C (Ebert 1979a):

$\begin{array}{llll}\text { a. /bəy-é/ bìn-ì 'to open' } & \text { b. /ta:k-é/ tá:k-é 'to let' } \\ \text { /gun-é/ } & \text { gùn-ì 'to wake [s.o.]' } & \text { /fel-é/ fél-é 'to find' } \\ \text { /zel-é/ } & \text { zèl-è 'to boil' } & \text { /dəg-é/ díg-í 'to think' } \\ \text { /var-é/ } & \text { vèr-è 'to choose' } & \text { /bal-é/ bél-é 'to nail' }\end{array}$

\footnotetext{
${ }^{6}$ The overall number of natural classes depends on the feature system used, and whether any features are defined as privative rather than binary (precluding reference to negative values). The calculations in (16) are based on a somewhat simplistic all-binary system, which generates a rather large number of natural classes, but this does not significantly affect the magnitude of the difference between the values in (16a) and (16b).
} 


\section{Voicing Agreement: An Evolutionary Perspective}

(18) Kera noun tones and phonation of root-initial C (Pearce 1998/99):

$\begin{array}{llll}\text { a. bàgàr 'antelope' } & \text { b. } & \text { kēelēw 'horn' } \\ \text { dà:rò 'friend' } & \text { pónáj 'mountain' } \\ \text { gèné } & \text { 'men in bush' } & \text { Gō:rō 'bow and arrows' } \\ \text { zàbúl 'soap' } & \text { dárká 'ant hill' }\end{array}$

Given that implosives are not correlated with $\mathrm{L}$ tone, the hypothesis that voicing agreement in Chadic results from the analogical reinterpretation of patterns resulting from tone-voicing interaction helps explain why implosives fail to participate in the agreement system. The relative similarity of implosives vis-à-vis pulmonics to a potential target obstruent is simply irrelevant.

\section{The Residue: "True" Voicing Agreement?}

There remains a very small residue of cases where voicing agreement cannot, it seems, be "explained away" as being due either to the reanalysis of tone-voicing interaction or to the analogical extension of agreement in another laryngeal feature. However, these show important characteristics which are also typical of many other relatively rare types of consonantal agreement. One of these is an extreme sensitivity to trigger-target similarity, with agreement applying only to Cs which are identical in all other features (place, manner, etc.); in effect this means that implementation of voicing agreement always results in complete trigger-target identity. Secondly, these are all strictly root-internal cooccurrence restrictions that do not hold across morpheme boundaries.

The best known and perhaps clearest example is Ngbaka (Adamawa-Ubangi, Dem. Rep. of Congo; Thomas 1963, Mester 1988, Walker 2000, Hansson 2001, Rose and Walker 2004), where voicing agreement is parasitic on identity in place of articulation. Homorganic obstruents only cooccur to the extent that they agree in voicing (/pepu/ 'vent', /babã/ 'companion'), whereas no such restriction holds for heterorganic obstruents (/duka/ 'shoulder', /kebe/ 'fast').

In fact, voicing agreement in Ngbaka forms part of a bigger system, where on a scale $\{\mathrm{T}-\mathrm{D}-\mathrm{N} \mathrm{D}-\mathrm{N}\}$ homorganic combinations drawn from adjacent steps on the scale do not mix. Not only are homorganic mixed-voicing sequences prohibited (T vs. D), but so are homorganic mixed-nasality sequences (D vs. ${ }^{\mathrm{N}} \mathrm{D}$ and ND vs. N). Thus while words like /babã/ 'companion', /mbè:mbe/ 'snail' and /nané/ 'today' are well-formed, homorganic sequences like */b... mb/ or */n... ${ }^{\mathrm{n}} \mathrm{d} /$ are ruled out. When the consonants are heterorganic, by contrast, the restriction no longer applies (cf. /bá'gá/ 'jaw', /mà̀gà/ 'net').

Another case with somewhat similar properties is Hausa (West Chadic, Nigeria; MacEachern 1999, Hansson 2001), where ejectives and implosives are not allowed to cooccur within roots. This might be construed as voicing agreement among segments that already agree in [constricted glottis], and forms part of a larger generalization: in Hausa, two cooccurring [c.g.] segments must in fact be identical in all features, including voicing as well as place. 


\section{Gunnar Ólafur Hansson}

\section{Conclusions}

It appears that voicing agreement is a heterogeneous category of phenomena from a diachronic-evolutionary perspective, in that most cases have "unnatural" histories involving analogical reanalysis and/or analogical extension. In Kera and Ngizim, agreement is likely an indirect result of extensive interaction and interdependence between tone and laryngeal features, in particular between Low and [voice]. This explains the otherwise-anomalous behaviour of implosives in these voicing agreement systems. In Zulu and Ndebele, voicing agreement is likely secondary, due to an extension from aspiration to all laryngeal features. This may help explain why voicing agreement fails to affect non-initial velars even though non-initial [g] (but not $\left[\mathrm{k}^{\mathrm{h}}\right]$ ) is allowed. Such analogical extension may also have played a part in the development of agreement in Chaha. The small residue of remaining cases shows characteristics which are highly reminiscent of more common cooccurrence restrictions such as OCP-Place (see Frisch et al. 2004 and references cited there). Perhaps these, then, are the only examples of voicing agreement where psycholinguistic factors of speech planning are truly implicated.

\section{References}

Blevins, J. 2004a. Antigemination: Natural or unnatural history? BLS 29.

Blevins, J. 2004b. Evolutionary Phonology. Cambridge: Cambridge University Press.

Blevins, J. To appear. Consonant epenthesis: Natural and unnatural histories. In J. Good, ed., Explaining Linguistic Universals: Historical Convergence versus Universal Grammar. Oxford: Oxford University Press.

Blevins, J., and A. Garrett. 1998. The origins of consonant-vowel metathesis. Language 74:508-556.

Blevins, J., and A. Garrett. 2004. The evolution of metathesis. In B. Hayes, R. Kirchner, and D. Steriade, eds., Phonetically Based Phonology, 117-156. Cambridge: Cambridge University Press.

Bradshaw, M. 1999. A crosslinguistic study of consonant-tone interaction. Ph.D. diss., Ohio State University.

Ebert, K. 1979a. Sprache und Tradition der Kera (Tschad). Berlin: Reimer.

Ebert, K. 1979b. Consonant-tone harmony in Kera. In L. Bouquiaux, ed., Multilinguisme dans les domaines bantou du nord-ouest et tchadique. Paris: SELAF.

Frisch, S. 1996. Similarity and frequency in phonology. Ph.D. diss., Northwestern University.

Frisch, S., J. Pierrehumbert, and M. Broe. 2004. Similarity avoidance and the OCP. Natural Language and Linguistic Theory 22:179-228.

Garrett, A., and J. Blevins. To appear. Morphophonological analogy. In S. Inkelas and K. Hanson, eds., The Nature of the Word: Essays in Honor of Paul Kiparsky. Cambridge, MA: MIT Press. 
Hansson, G. 2001. Theoretical and typological issues in consonant harmony. Ph.D. diss., University of California, Berkeley.

Hansson, G. 2004. Tone and voicing agreement in Yabem: Representations vs. constraint interaction. WCCFL 23:318-331.

Hombert, J.-M. 1978. Consonant types, vowel quality, and tone. In V. A. Fromkin, ed., Tone: A Linguistic Survey, 77-112. New York: Academic Press.

Hyman, L. 1999. Aspiration and voicing harmony in Nguni? Handout from seminar presentation, UC Berkeley, September 1999.

Hyman, L., and R. Schuh. 1974. Universals of tone rules: evidence from West Africa. Linguistic Inquiry 5:81-115.

Khumalo, J. 1987. An autosegmental account of Zulu phonology. Ph.D. diss., University of Witwatersrand.

MacEachern, M. 1999. Laryngeal Cooccurrence Restrictions. New York: Garland.

Mester, R. A. 1988. Studies in Tier Structure. New York: Garland.

Pearce, M. 1998/99. Consonants and tone in Kera (Chadic). Journal of West African Languages 27:33-70.

Poser, W. 1981. On the directionality of the tone-voice correlation. Linguistic Inquiry 12:483-488.

Rose, S., and L. King. 2003. Speech errors as a test of co-occurrence constraints in the lexicon of two Semitic languages. Paper presented at the Markedness and Lexicon Workshop, MIT, January 2003.

Rose, S., and R. Walker. 2000. Long-distance consonant agreement. Paper presented at NELS 31, Georgetown University, October 7, 2000.

Rose, S., and R. Walker. 2004. A typology of consonant agreement as correspondence. Language 80:475-531.

Schuh, R. 1971. Verb forms and verb aspects in Ngizim. Journal of African Languages 10:47-60.

Schuh, R. 1978. Bade/Ngizim vowels and syllable structure. Studies in African Linguistics 9:247-283.

Schuh, R. 1997. Changes in obstruent voicing in Bade/Ngizim. Ms., UCLA.

Thomas, J. 1963. Le parler ngbaka de Bokanga. Paris: Mouton.

Uffmann, C. 2003. Optimal geometries. Paper presented at the Old World Conference in Phonology (OCP-1), Leiden University, January 2003.

Walker, R. 2000. Long-distance consonantal identity effects. WCCFL 19:532-545.

Dept. of Linguistics, Univ. of British Columbia

Buchanan E270, 1866 Main Mall

Vancouver, B.C. V6T 1Z1

Canada

ghansson@interchange.ubc.ca 